\title{
PENGEMBANGAN PERANGKAT PEMBELAJARAN PAI DENGAN PENDEKATAN SAINTIFIK UNTUK MENINGKATKAN KEMAMPUAN BERPIKIR KREATIF SISWA SMA
}

\author{
Mokh. Imron Rosyadi \\ IAIN Pekalongan \\ mokhimron.13@gmail.com
}

\begin{abstract}
Abstrak
Tujuan dari penelitian ini adalah mengembangkan perangkat pembelajaran PAI dengan menggunakan teori pengembangan Borg And Gall yang terdiri dari 10 tahapan. Data diperoleh melalui instrumen berupa lembar observasi, panduan wawancara dan angket, kemudian dianalisis secara deskriptif. Berdasarkan hasil penilaian validator bahwa perangkat pembelajaran tersebut dinyatakan valid dan efektif. Terbukti dapat meningkatkan aktivitas pembelajaran dan mampu meningkatkan kemampuan berpikir kreatif siswa. Perangkat pembelajaran yang telah dikembangkan dalam penelitian ini dapat digunakan oleh guru PAI dan dapat digunakan sebagai motivasi untuk selalu mengembangkan kompetensi profesionalisme terutama dalam proses pembelajaran.
\end{abstract}

Kata kunci: pendekatan saintifik, berpikir kreatif, Pembelajaran PAI

\begin{abstract}
The purpose of this study is to develop a PAI learning kit by using the development of the Borg And Gall theory which consists of 10 stages. Data obtained through instruments in the form of observation sheets, interview guides and questionnaires, then analyzed descriptively. Based on a valid judgment decision that the learning tool is declared valid and effective. Proven to increase activity learning and be able to increase students' creative power. The learning tools that have been developed in this study can be used by PAI teachers and can be used as motivation to always develop professional competence, especially in the learning process.
\end{abstract}

Keywords: scientific approach, creative thinking, PAI learning 


\section{A. PENDAHULUAN}

Mata pelajaran PAI merupakan salah satu disiplin ilmu yang membahas sendisendi ajaran Islam secara formal pada setiap jenjang pendidikan di Indonesia, meliputi aqidah, akhlak, hukum (syariah), sejarah kebudayaan Islam dari jazirah Arab hingga penyebarannya ke nusantara, serta tokoh-tokoh intelektual muslim pada abad pertengahan. (Jamali Sahrodi, 2008: 37). Dalam perjalanaan sejarah, proses pengkajiaan Islam mencerminkan suatu transmisi doktrin-doktrin keagamaan dari generasi ke generasi dengan menjadikan tokoh-tokoh agama, para ulama, pejuang Islam, pemimpin, ilmuwan dan lain sebagainya sebagai pionirnya.

Pendidikan agama menjadi mata pelajaran wajib pada setiap satuan pendidikan di Indonesia guna mewujudkan bangsa yang berkarakter dan berakhlak mulia, hal tersebut sesuai dengan amanat UU nomor 20 tahun 2003. Di sisi lain UNESCO juga telah merumuskan empat pilar pendidikan yakni learning to know, learning to do, learning to be dan learning to live together menjadi acuan penting dalam menyelenggarakan pendidikan. Dengan harapan perubahan perilaku dapat dilakukan melalui pendidikan dan melalui proses pembelajaran yang berkualitas dapat memunculkan potensi manusia yang selalu memiliki rasa ingin tahu yang tinggi. Artinya kalau perubahan perilaku ke arah yang lebih baik tidak tercapai dan rasa ingin tahu siswa terhadap apa yang telah dipelajarinya tidak muncul berarti guru telah gagal menjalankan tugasnya.

Mata pelajaran PAI sangatlah kompleks, luas, dan mendalam yang meliputi berbagai sendi kehidupan umat Islam. Dimensi teoritis pembelajarannya lebih bertujuan untuk mendapatkan "instructional effect" dari apa yang telah diajarkan, sedangkan pada dimensi yang bersifat praktis memiiki maksud agar berbagai bentuk ibadah harus diamalkan sesuai dengan tuntunannya (syariah), asumsinya pembelajaran ini bukan hanya berkenaan dengan kognitif saja, akan tetapi harus menjadi karakter secara afektif dan dituangkan dalam perbuatan (psikomotorik) siswa (Ismail, 2008 : 23). Beberapa hal yang perlu kita identifikasi adalah bagaimana proses pembelajaran PAI ini dilakukan oleh guru, mulai dari pengembangan pelaksanaan pembelajarannya hingga sampai instrumen evaluasi 
yang dirancang untuk mencapai setiap kompetensi hasil belajar. Kalau melihat kenyataan memang hasil belajar mata pelajaran PAI sebenarnya memuaskan, tapi hal ini seperti tidak memiliki pengaruh terhadap sikap yang seharusnya mereka tampilkan.

Pemaknaan siswa terhadap ajaran agama dapat ditentukan oleh penafsiran dan pemahamannya terhadap teks-teks keagamaan, yakni Al Qur'an dan Hadist. Pemaknaan dalam pandangan aliran pendidikan konstruktivistik dapat dibentuk oleh stimulus eksternal (pengalaman apa yang dilihat, diraba dan didengarkannya), kemudian dikonstruksi oleh dan dari dalam diri siswa. Keterkaitan antara stimulus eksternal dengan pengetahuan awal siswa (pre-understanding) pada gilirannya membuahkan pemahaman dan pemaknaan yang inheren dalam dirinya. (Bimo Walgito, 1990: 54).

Persepsi, pemahaman dan pemaknaan tersebut selanjutnya menimbulkan sikap dan perilaku yang menggerakkan munculnya perbuatan nyata dari siswa. Logika tersebut dapat muncul dalam diri siswa karena berdasarkan asumsi bahwa pemaknaan bukanlah tentang hal yang terlepas dari penginderaan, tetapi merupakan ciptaan individu yang dikonstruksi melalui pengalaman yang dialaminya. (Paulina, 2001: 3). Proses pendidikan yang mampu menggabungkan kedua fakta diatas seyogyanya menjadi perhatian penting oleh pengamat maupun praktisi pendidikan. Oleh karena itu, penelitian ini fokus pada pengembangan pembelajaran pada ranah afektif mata pelajaran PAI melalui pendekatan saintifik untuk meningkatkan potensi berpikir kritis siswa pada jenjang SMA.

Kemudian langkah yang akan dilakukan adalah memilih model pengembangan dalam merancang desain pembelajaran dengan pendekatan saintifik pada mata pelajaran PAI. Guna mendapatkan desain produk yang efektif pada mata pelajaran PAI tingkat SMA, maka dalam penelitian ini akan menggunakan metode penelitian dan pengembangan $(R \& D)$. Menurut Sugiyono bahwa metode penelitian ini sangat relevan digunakan untuk menghasilkan produk tertentu yang memerlukan analisis kebutuhan, yakni melalui survey, selanjutnya dilakukan uji keefektifannya agar produk tersebut dapat berfungsi bagi tercapainya perubahan perilaku 
berlandaskan proses berpikir melalui pengembangan pendekatan saintifik. (Sugiono, 2011: 378).

\section{B. PEMBAHASAN}

\section{Pengembangan Perangkat Pembelajaran PAI}

Pembelajaran menurut Sagala (2010), merupakan proses komunikasi dua arah, mengajar dilakukan oleh pihak guru sebagai pendidik, sedangkan proses belajar dilakukan oleh siswa. Menurut Trianto (2007), hakikat pembelajaran adalah usaha sadar dari seorang guru untuk membelajarkan siswanya (mengarahkan interaksi siswa dengan sumber belajar lainnya) dalam rangka mencapai tujuan yang diharapkan. Pembelajaran sebagai proses belajar yang dibangun oleh guru untuk mengembangkan kreativitas yang dapat meningkatkan kemampuan berpikir siswa dan mengkonstruksi pengetahuan baru sebagai upaya meningkatkan penguasaan yang baik terhadap materi pembelajaran.

Pembelajaran merupakan suatu proses yang sistematis melalui tahap perencanaan, pelaksanaan dan evaluasi (Knirk \& Gustafson dalam Sagala, 2010). Dalam hal ini pembelajaran tidak terjadi seketika, melainkan sudah melalui tahapan desain pembelajaran secara sistematis. Oleh sebab itu diperlukan konsep tentang pembelajaran yang akan menjelaskan asas-asas untuk merancang pembelajaran yang efektif dikelas. Sehingga persiapan terhadap berbagai ruang lingkup desain pembelajaran penting dalam memilih model, pendekatan dan strategi dalam mengimplementasikan proses pembelajaran dengan tujuan agar pengalaman belajar yang berpusat pada siswa mampu memunculkan potensi berpikir siswa.

Mengingat begitu pentingnya menciptakan pembelajaran yang mampu mengkonstruksi berbagai pengalaman belajar bermakna bagi siswa, maka mengembangkan model profetik perlu dilakukan dengan serius. (Fauzi, Ahmad, 2017, Vol 4). Disisi lain, mengembangkan inovasi pembelajaran yang mampu memunculkan pola berpikir tingkat tinggi juga tidak kalah penting untuk dilakukan. Proses pembelajaran PAI sangat erat kaitanya dengan perubahan perilaku sebagai hasil belajarnya, karena indikator keberhasilan proses yang sebenarnya dapat diukur 
dari bagaimana merancang pola instruksional yang relevan dengan tujuan pembelajaran yang akan dicapai.

Adapun pengembangan yang dilakukan yaitu menggunakan model Borg \& Gall, yakni diawali dengan kegiatan analisis kebutuhan sehingga diperoleh perangkat pembelajaran hipotetik menggunakan metode penelitian kualitatif. (Ningrum, 2018). Selanjutnya dilakukan proses pengujian secara bertahap guna menyempurnakan produk yang masih bersifat hipotetik tersebut melalui kegiatan eksperimen. Pada tahap akhir pengujian dan penilaian pada setiap tahapan eksperimen produk ini dapat diaplikasikan kepada penggunanya, khususnya bagi mahasiswa jurusan PAI sebagai persiapan praktik mengajar dan kemudian bagi guru PAI pada jenjang SMA. Selanjutnya secara rinci tahapan dalam kegiatan penelitian dengan model pengembangan Borg \& Gall adalah sebagai berikut :

\section{Research and Information Collecting}

Pada tahap awal ini adalah melakukan studi literatur berkaitan dengan permasalahan yang dikaji, observasi terhadap objek, dan persiapan untuk merumuskan kerangka kerja penelitian. Termasuk pembentukan TIM yang akan dilibatkan dalam merancang perangkat pembelajaran. Dari kegiatan ini melakukan diskusi dengan nara sumber yakni guru PAI di SMA N 1 Kramat Tegal tentang materi yang akan dijadikan model untuk dikembangkan, kelas dan jadwal pelaksanaan uji coba.

Kegiatan observasi ditujukan untuk memahami perilaku awal dan karakteristik siswa, guru dapat menetapkan aktivitas dan strategi pembelajaran yang tepat sesuai dengan karakteristik, kebutuhan, dan cara belajar siswa. Kegiatan pembelajaran akan lebih bermakna dan menyenangkan bagi siswa, dan pada akhirnya aktivitas belajarnya dapat berlangsung secara optimal dan produktif. Hal ini diasumsikan bahwa minat, kemauan, kebiasaan, dan cara belajar sangat berpengaruh terhadap aktivitas belajar siswa di kelas.

Berdasarkan hasil diskusi tentang materi pelajaran diperoleh kesepakatan bahwa pokok bahasan yang dipilih adalah "Merawat Jenazah" kelas XI, kemudian menyusun rencana dan mendiskusikan bagaimana pokok bahasan tersebut akan diimplementasikan dalam kegiatan pembelajaran, model 
pembelajaran, strategi, media serta menentukan pelaksanaan uji awal dan memilih siswa secara acak dan heterogen berdasarkan kemampuannya dalam memahami mata pelajaran PAI.

Kondisi siswa yang ideal adalah kondisi di mana siswa siap menerima pelajaran, baik secara fisik berupa kesegaran jasmani, dan secara psikologis yakni mampu mengoptimalkan pengetahuan dan keterampilan yang dimilikinya. Sehingga akan diperoleh hasil belajar secara maksimal sesuai dengan kemampuan yang dimilikinya. Dengan mengetahui kondisi fisik dan psikologis siswa, diharapkan guru dapat menyusun rencana dan langkah-langkah pembelajaran secara efektif, sehingga tujuan pembelajaran yang diharapkan dapat tercapai dengan sebaik-baiknya.

Cara belajar siswa juga bermacam-macam, ada beberapa siswa dapat belajar dengan maksimal apabila telah mendengarkan penjelasan guru, sebagian siswa lebih mudah belajar dengan melihat langsung gambar atau diagram, sebagian yang lain lebih suka belajar dengan buku dan bahan-bahan cetak lain, dan sebagian siswa yang lain lagi lebih suka berkelompok dan saling berinteraksi.

Kebiasaan-kebiasaan cara belajar siswa tersebut perlu mendapatkan perhatian guru, sehingga guru dapat menetapkan program pembelajaran yang tepat sesuai dengan kebiasaan siswa. Tentu saja tidak seluruh kebiasaan siswa dapat terlayani dalam pelaksanaan pembelajaran di sekolah. Setidaknya dengan memahami kebiasaan-kebiasaan siswa, guru dapat lebih menyesuaikan diri dan dapat lebih banyak melayani kebutuhan siswa. Untuk mendapatkan pemahaman tentang minat, motivasi, dan cara belajar siswa terkait dengan kegiatan pembelajaran yang akan dilakukan, maka sebelum memulai pembelajaran guru penting untuk melakukan identifikasi perilaku awal guna mengetahui karakteristik siswa.

Dengan memahami perilaku awal dan karakteristik siswa, guru dapat menetapkan teknik, metode, dan strategi pembelajaran yang tepat sesuai karakteristik, kebutuhan, dan cara belajar siswa. Sehingga kegiatan pembelajaran akan lebih bermakna dan menyenangkan bagi siswa, dan pada akhirnya kegiatan pembelajaran dapat berlangsung secara optimal dan produktif. 
Hal ini disebabkan, karena minat, kemauan, kebiasaan, dan cara belajar sangat berpengaruh terhadap keberhasilan siswa dalam belajar. Untuk mendapatkan pemahaman tentang minat, kemauan, kebiasaan, dan cara belajaran siswa, sebelum pembelajaran berlangsung guru perlu melakukan identifikasi terhadap perilaku awal dan karakteristik siswa. Dengan mengetahui minat, kemauan, kebiasaan, dan cara belajar siswa maka guru dapat memilih teknik, metode, dan strategi pembelajaran yang tepat sesuai dengan kebutuhan siswa.

\section{Planning}

Yakni tahapan untuk menyusun rencana pengembangan perangkat pembelajaran yang dimulai dengan merumuskan kecakapan atau keahlian yang berkaitan dengan permasalahan, menentukan tujuan yang akan dicapai pada setiap tahapan pengembangan, desain pengembangan dan melaksanakan studi kelayakan secara terbatas.

Pokok bahasan dalam silabus dilaksanakan dengan dua kali tatap muka, pertama memahami pelaksanaan tata cara merawat jenazah, indikator yang harus tercapai adalah siswa mempu menjelaskan secara teoritis hal-hal yang berkaitan dengan prosesi tata cara merawat jenazah. Kemudian pada pertemuan ke dua adalah memperagakan tata cara merawat jenazah, indikatornya adalah siswa mampu mempraktekan tata cara merawat jenazah.

\section{Develop Preliminary Form Of Product}

Setelah ditentukan pokok bahasan, kompetensi inti, kompetensi dasar dan indikator pencapaiannya, pada tahapan ini adalah mengembangkan desain permulaan dari perangkat pembelajaran merawat jenazah, selanjutnya menyiapkan komponen pendukung berupa model pembelajaran, strategi, media pembelajaran dan RPP sebagai pedoman implementasinya. Kemudian perlu dipersiapkan pula instrumen untuk melakukan evaluasi terhadap kelayakan alatalat pendukung seperti pengembangan bahan pembelajaran, acuan proses pembelajaran, dan instrumen evaluasi.

Berdasarkan hasil diskusi dengan TIM dan guru PAI dibuat lembar kerja kelompok untuk membahas prosesi merawat jenazah dalam kondisi khusus. Adapun kematian dalam kondisi khusus tersebut meliputi : 1) kematian yang dikarenakan musibah kebakaran sehingga korban tidak utuh lagi, 2) kematian 
dikarenakan kecelakaan lalu lintas yang membuat tubuh korban tercecer dan tak berbentuk lagi, 3) kematian yang diakibatkan korban pembunuhan dan telah dikuburkan oleh pelaku dan baru ditemukan beberapa bulan setelah kejadian, dan 4) adalah kematian dari pembunuhan yang dilakukan dengan cara mutilasi.

\section{Preliminary Field Testing}

Melakukan uji coba awal desain perangkat pembelajaran pokok bahasan merawat jenazah dalam skala terbatas kepada beberapa siswa kelas XI sebanyak 5 - 10 siswa dan membaginya menjadi dua kelompok. Pada tahap ini pengumpulan dan analisis data dilakukan dengan lembar observasi pelaksanaan pembelajaran dengan pendekatan saintifik yang meliputi : keterlibatan individu dalam menyelesaikan tugas kelompok, keaktifan individu dalam mendiskusikan lembar kerja kelompok, kemampuan setiap individu dalam bertanya dan mengungkapkan pendapatnya, sikap setiap individu sebagai pendengar aktif dalam proses diskusi dan kemampuan setiap kelompok dalam menyimpulkan hasil diskusi kelompoknya masing-masing. Hal yang perlu dijadikan catatan adalah kemampuan awal siswa dan keterlibatan siswa dalam menyelesaikan lembar kerja secara berkelompok.

Setelah dilakukan uji coba diberikan angket dan dilakukan pendalaman informasi dengan melakukan wawancara tentang respon siswa terhadap desain model dan pembaharuan dalam proses pembelajaran. Beberapa aspek yang menjadi acuan dalam pengembangan ini adalah guru harus melakukan upayaupaya yang produktif dalam merancang kegiatan belajar mengajarnya, seperti beberapa hal berikut : 1) Memulai dengan memperkenalkan tujuan pembelajaran sehingga siswa mengetahui dengan jelas apa yang harus dicapai dalam proses belajar itu. 2) Memberikan kebebasan pada siswa untuk memperluas kegiatan dan materi belajar, selama tidak keluar dari daerah belajar yang pokok. 3) Memberi kesempatan kepada siswa untuk mengembangkan potensi mereka dengan memanfaatkan sumber belajar yang ada. 4) Membentuk kelompok yang beranggotakan siswa yang bermotivasi intrinsik dengan siswa yang bermotivasi ekstrinsik sehingga terjadi pertukaran pengalaman. 5) Memberikan apresiasi atas hasil kerja siswa. Dan 6) Memberikan kritik yang membangun demi peningkatan kualitas belajarnya. 


\section{Main Product Revision}

Yaitu melakukan perbaikan terhadap produk awal yang dihasilkan pada saat kegiatan uji coba lapangan skala terbatas. Berdasarkan kegiatan pada tahap ke empat terjadi beberapa permasalahan yang berkaitan dengan alokasi waktu yang tersedia dan kesiapan siswa dalam menyelesaikan tugas kelompok. Adapun lembar kerja tersebut adalah yang berkaitan dengan prosesi perawatan jenazah dalam kondisi khusus. Referensi yang disediakan belum memenuhi kebutuhan siswa untuk membahas permasalahan yang ada dalam lembar kerja kelompok tersebut.

Sehingga pada proses uji coba pada tahap berikutnya siswa diperbolehkan mengerjakan tugas di luar kelas sebagai PR, siswa dianjurkan mencari bahan jawaban dengan mengakses informasi secara daring dan kemudian dikonsultasikan dengan melakukan wawancara kepada nara sumber yang lebih ahli dalam permasalahan tersebut. Dalam hal ini setiap kelompok sangat dianjurkan melakukan wawancara kepada ustadz atau kiai yang memiliki latar belakang organisasi keislaman yang beragam, yakni ustadz atau kiai dari NU, Muhammadiyah, Salafi, bahkan dari LDII yang memang ada di wilayah kecamatan Kramat, kabupaten Tegal.

\section{Main Field Testing}

Merupakan tahapan yang penting, karena pada tahap ini adalah kegiatan uji coba utama yang melibatkan pihak secara lebih luas lagi dibandingkan pada tahap ke empat. Pengumpulan data dilakukan secara kuantitatif, terutama terhadap kualitas produk sebelum dan sesudah penerapan uji coba. Hasil yang dihimpun dari tahapan ini merupakan evaluasi terhadap pencapaian hasil uji coba (desain perangkat), pada tahap ini jika memungkinkan menggunakan rancangan penelitian eksperimen dengan cara membandingkan dengan kelompok kontrol.

\section{Operational Product Revision}

Melakukan perbaikan dan penyempurnaan produk terhadap hasil uji coba pada tahap ke enam, sehingga produk hasil pengembangan pada tahap ini merupakan desain perangkat pembelajaran yang siap di validasi. Setelah dilakukan perbaikan pada strategi pembelajaran dan pengembangan sumber 
belajar, maka dilakukan validasi oleh validator ahli untuk mendapatkan pengakuan terhadap efektifitas perangkat pembelajaran PAI pokok bahasan merawat jenazah dalam kondisi khusus.

\section{Operational Field Testing}

berdasarkan uji validasi terhadap perangkat pembelajaran yang telah dihasilkan dengan melibatkan validator ahli, pada tahap ini desain akan diimplementasikan kepada siswa dalam proses pembelajaran di kelas. Kegiatan ini melibatkan dua kelas yakni kelas XI IPA 2 dan Kelas XI IPS 3.

\section{Final Product Revision}

Proses yang dilakukan dalam tahap ini adalah melakukan perbaikan akhir terhadap perangkat pembelajaran yang dikembangkan pada tahap sebelumnya guna menghasilkan produk final. Suasana belajar yang terjadi pada waktu berlangsungnya proses pembelajaran, meliputi keadaan fisik dan mengorganisir sumber belajar di dalam kelas telah diatur sedemikian rupa guna menunjang proses belajar, yang tidak kalah penting dalam hal ini adalah keadaan non fisik terkait interaksi guru dan siswa, interaksi antar siswa dan sikap siswa terhadap mata pelajaran. Upaya guru sebagaimana yang telah dijadikan acuan sebagaimana disebutkan pada tahap ke empat yang terdiri dari enam aspek peningkatan kinerja guru dan performannya dalam membimbing pengalaman belajar yang berpusat pada siswa.

Kondisi kelas yang nyaman dan suasana kejiwaan yang menyenangkan (enjoy) merupakan faktor penting untuk terciptanya situasi yang kondusif guna menunjang keberhasilan dalam berbagai kegiatan khususnya keberhasilan dalam proses belajar dan mengajar. Untuk merealisasikan hal tersebut telah dirancang berbagai kegiatan, meliputi kegiatan investigasi (yakni pendekatan saintifik yang terdiri dari mengetahui, memahami dan mengaplikasikan) dilakukan sebelum kegiatan pembelajaran di kelas (mengkaji referensi baik dari buku maupun internet dan melakukan konsultasi kepada ustadz atau kiai), diskusi kelompok, presentasi hasil diskusi dan dilanjutkan dengan tanya jawab (merupakan interpretasi dari mengkomunikasikan dan mencipta). 


\section{Dissemination And Implementation}

Tahap akhir adalah menyebarluaskan produk/ perangkat pembelajaran hasil pengembangan terhadap User dan stake holder yang konsen terhadap pembelajaran. Namun berkaitan dengan kegiatan ini peneliti mengalami kendala yang berhubungan terbatasnya waktu dan biaya, sehingga desain perangkat pembelajaran ini hanya didiseminasikan secara luas.

\section{Implementasi Pendekatan Saintifik}

Pendekatan saintifik pada dasarnya merupakan suatu pendekatan yang diadopsi dari taksonomi pengetahuan yang dikembangkan oleh Benjamin S. Bloom (New York, 1956: 20 - 24), selanjutnya taksonomi revisi yang dikembangkan oleh Krathwoll dengan mengklasifikakan tingkatan dalam berpikir pada ranah kognitif. (Benny A. Pribadi, 2016: 92). Adapun penerapan pendekatan saintifik pada pembelajaran PAI pokok bahasan merawat jenazah berdasarkan taksonomi tersebut di atas, secara berurutan adalah sebagai berikut:

\section{Mengingat}

Merupakan kemampuan berpikir paling dasar yakni suatu proses yang mengandalkan ingatan dalam proses belajar, dalam hal ini adalah kemampuan siswa dalam mengetahui tata cara merawat jenazah yang dimulai dengan tata cara memandikan, mengkafani, menyolatkan, dan menguburkan.

Tahapan ini sebisa mungkin dilakukan oleh siswa kelas XI melalui pemberian tugas menghimpun informasi dan membaca referensi mengenai ke empat tata cata perawatan jenazah.

2. Memahami

Jenjang kedua yakni kemempuan siswa untuk memahami dan menjelaskan mengapa jenazah harus dimandikan (disucikan) terlebih dahulu, bagaimana cara mengkafani, menjelaskan mengapa harus dishalatkan dan mengapkela shalatnya berdiri (tanpa ruku' dan sujud), serta mengapa harus dibuatkan liang lahat pada tempat menguburkannya.

Pada tahap ini selain siswa menghimpun infomasi melalui literatur dan referensi, siswa juga perlu melakukan wawancara atau konsultasi kepada ustadz yang ada dilingkungan masyarakatnya. Dalam hal ini siswa disarankan untuk 
melakukan penggalian informasi dari ustadz atau kiai yang memiliki latar belakang beragam, misalnya ustadz dari NU, Muhammadiyah, salafi dan ustadz dari LDII. Kegiatan tersebut dilakukan siswa secara berkelompok dan tugas tersebut diberikan kepada satu minggu sebelum tatap muka sebagai pekerjaan rumah (PR).

3. Menerapkan

Jenjang ketiga adalah kemampuan siswa dalam mempraktikan tata cara memandikan, mengkafani, menyolatkan, dan menguburkan. Proses ini dilakukan oleh siswa dengan cara melihat video tata cara tersebut melalui chanel penyedia berbagi video maupun dari blog secara daring. Pada saat tatap muka pertama siswa secara berkelompok diberi tugas untuk mempraktekan, bentuk kegiatan pembelajarannya dengan cara membagi kelas XI menjadi empat kelompok (sesuai dengan jumlah sub pokok bahasan). Setiap kelompok mempraktekan tata cara merawat jenazah dan tiga kelompok lainya memberikan penilaian dan pertanyaan terkait prosesi yang sedang dipraktekan.

4. Menganalisis

Jenjang keempat adalah kemampuan siswa dalam memanfaatkan informasi yang telah diperolehnya kemudian mengembangkannya menjadi pendapat atau buah pemikiran dari setiap individu. Hal ini dilakukan pada saat tatap muka kedua, kemampuan berpikir kritis siswa dapat diamati ketika mendiskusikan kematian dalam kondisi khusus.

Bentuk kegiatan pembelajarannya dengan cara membagi kelas menjadi empat kelompok. Langkah selanjutnya memberikan lembar kerja kelompok yang berisi tugas : 1) mendiskusikan tata cara merawat jenazah yang menjadi korban kebakaran, 2) mendiskusikan tata cara merawat jenazah korban pembunuhan yang telah dikuburkan pelakunya hingga beberapa bulan, 3) mendiskusikan tata cara merawat jenazah korban kecelakaan hingga tubuhnya tercecer, 4) mendiskusikan tata cara merawat jenazah korban pembunuhan mutilasi. Untuk memudahkan siswa dalam memahami keadaan masing-masing keadaan jenazah, guru dapat menampilkan kondisi tersebut dalam bentuk gambar. 


\section{Mencipta}

Pada pendekatan berpikir tingkat tinggi ini dapat dilihat dari bagaimana cara siswa menanggapi presentasi kelompok lain yang membahas kematian dalam kondisi khusus yang berbeda kasus antara satu kelompok dengan kelompok lainnya.

Kemudian kemampuan siswa dalam mencipta ini dapat dilihat dari bagaimana cara siswa menghadapi perbedaan pendapat yang memang dalam perbedaan tersebut masing-masing pendapat atau hasil wawancara dari beragam ustadz atau kiai yang memang berasal dari latar belakang organisasi keagamaan yang berbeda pula. Sebagaimana disebutkan diatas tadi yakni ustadz atau kiai dari NU, Muhammadiyah, Salafi dan LDII. Berkaitan dengan hal ini adalah sikap dan toleransi siswa terhadap berbagai pendapat dan mengkaji lebih dalam lagi pedoman hukum yang digunakan oleh ustadz atau kiai dalam mengambil kesimpulan dalam merespon permasalahan tentang kematian dalam kondisi khusus dengan beragam kasus kematiannya.

Implementasi pendekatan saintifik sebagaimana tersebut di atas menggambarkan aktifitas dan tingkah laku yang diawali dari keterampilan berpikir tingkat rendah (basic thinking skill), yakni mengetahui, memahami, dan menerapkan, (Elizabeth Tjahjadarmawan, 2016: 12), yang dalam penelitian ini dilakukan oleh siswa sebelum tatap muka dilakukan. Adapun strategi yang digunakan adalah melalui pemberian tugas kepada siswa pada pertemuan sebelumnya.

Pada tahap selanjutnya yakni menerapkan keterampilan berpikir tingkat tinggi (higher order thinking skill), dalam proses pembelajaran di kelas keterampilan tersebut meliputi beberapa aspek yang dimulai dari mengumpulkan informasi, menseleksi informasi, menganalisis informasi, dan kemudian membuat kesimpulan berdasarkan informasi yang diperolehnya (Elizabeth Tjahjadarmawan, 2016 : 13). Dalam penelitian keterampilan berpikir tingkat tinggi ditunjukan pada saat siswa menyelesaikan tugas prosesi perawatan jenazah dalam kondisi khusus sebagaimana disebutkan pada tahap ke dua dalam pengembangan perangkat pembelajaran. 
Hal penting yang sangat dibutuhkan oleh siswa adalah bagaimana mereka mengkonstruksi pengetahuan, agar pengetahuan tersebut benar-benar dikuasai, difahami dan diamalkan dengan baik serta bertanggung jawab, maka untuk mengakomodasi berbagai kebutuhan tersebut dalam penelitian ini dengan menggunakan pendekatan saintifik dan metode diskusi kelompok dalam proses pembelajaran. Sehingga melalui proses berpikir berdasarkan jenjang kognitif yang terdapat dalam taksonomi tersebut mampu merubah perilaku siswa ke arah yang lebih baik melalui pengembangan logika berpikir dan toleransi terhadap perbedaan yang masing-masing pendapat tersebut memiliki pedoman dalam memutuskannya.

Konsep tersebut didasarkan atas pandangan bahwa masyarakat merupakan tempat praktek atau laboratorium belajar yang lebih besar dari pada sekolah. Siswa mendapatkan pengalaman-pengalaman yang riil di masyarakat, yakni dengan cara menghubungkan siswa dengan masyarakat melalui kegiatan wawancara atau konsultasi permasalahan pada mata pelajaran PAI yang memang membutuhkan ahli dalam menyelesaikan masalah tersebut dapat digunakan untuk mengembangkan potensi berpikir dan menganalisis informasi sesuai dengan fenomena yang terjadi di lingkungan masyarakatnya.

Fenomena di atas mengharuskan lembaga sekolah melalui proses pembelajaran dapat berfungsi maksimal menyiapkan siswanya untuk menghadapi berbagai masalah dalam kehidupannya baik di dalam rumah tangga maupun di masyarakat. Hal itulah yang menyebabkan siswa harus dibekali berbagai keterampilan-keterampilan yang diperlukan dalam kehidupan nyata serta dibimbing agar dapat mengatasi berbagai persoalan dan mencari solusi penyelesaiannya dengan menyandarkan pada Al Qur'an, Hadist maupun Ijma' bukan berdasarkan pemikiran sendiri yang tanpa menggantungkan pada pedoman agama Islam.

\section{SIMPULAN}

Berdasarkan hasil penelitian bahwa pengembangan perangkat pembelajaran PAI untuk menggali potensi berpikir kreatif siswa tingkat SMA dengan pendekatan saintifik berdasarkan model yang dikembangkan oleh Borg \& Gall, kemudian dianalisis secara deskriptif dapat diambil kesimpulan sebagai berikut : 
1. Kegiatan belajar mengajar mata pelajaran PAI untuk materi Merawat Jenazah kelas XI SMA N 1 Kramat yang telah berjalan selama ini masih belum efektif, karena siswa belum mampu memahami secara komprehenship terkait materi tersebut diatas dan alokasi waktunya adalah 2 kali pertemuan atau 4 x 45 menit terasa masih kurang. Namun dengan melakukan inovasi pada pendekatan saintifik dan pengembangan media pembelajaran agar lebih menggali potensi berpikir kritis siswa dapat mengatasi permasalahan tersebut.

2. Pengembangan perangkat pembelajaran dalam penelitian ini meliputi desain instruksional, pendekatan pembelajaran, dan menyediakan media pembelajaran yang telah divalidasi oleh ahli dan dalam uji coba teoritik mendapatkan nilai rata-rata 79 atau dalam predikat baik. Adapun perbaikan yang harus dilakukan yakni berkaitan dengan alur pengembangan materi, kemudahan dalam mengakses sumber belajar dan pemberian tugas harus dilakukan pada pertemuan sebelumnya.

3. Hasil uji coba terbatas perangkat pembelajaran PAI materi Merawat Jenazah menggunakan pendekatan saintifik mampu meningkatkan aktivitas belajar yang mampu menggali potensi berpikir kritis siswa. Peningkatan aktivitas belajar dibuktikan dengan penilaian oleh observer tentang keterlibatan siswa dalam mendiskusikan tugas (berdasarkan lembar kerja kelompok) dan meningkatkan proses berpikir kritis (mengungkapkan pendapatnya) dalam proses diskusi tersebut dan dalam menanggapi hasil presentasi dari kelompok lain.

Pengembagan pengalaman belajar siswa agar mencapai sikap (afeksi) yang merupakan inti dari perubahan perilaku dengan mengimplementasikan perangkat pembelajaran yang telah telah dikembangkan mampu meningkatkan aktivitas belajar dan proses berpikir kreatif siswa. Berdasarkan uji coba yang telah dilakukan dalam peneliytian ini mengindikasikan bahwa produk hasil pengembangan menggunakan pendekatan saintifik ini dapat diterapkan pada skala yang lebih luas. 


\section{Daftar Pustaka}

Anisoyomukti, Nur, Teori-teori pendidikan, Jogjakarta: Arruzz Media, 2013.

Azwar, Saifudin, Penyusunan Skala Psikologi, Yogyakarta: Pustaka Pelajar, 2011. , Sikap Manusia : Teori dan Pengukurannya, Yogyakarta: Pustaka Pelajar, 2011.

Bloom, Benjamin S., Taxonomy of Educational Objectives, Vol. 1, Cognitive Domain, New York, McKay, 1956.

Fauzi, Ahmad, Daya Serap Siswa Terhadap Pembelajaran Taksonomi Pendidikan Agama Islam, Jurnal Pusaka, IAI Al Qolam Malang, Vol. 4, No. 2, Edisi 8, 2017, url : ejournal.alqolam.ac.id/index.php/jurnal_pusaka/article.

Ismail, SM, Strategi Pembelajaran Agama Islam Berbasis PAIKEM, Semarang : Rosail Media Group, 2008.

Kusaeri, Acuan Dan Teknik Penilaian Proses Dan Hasil Belajar Dalam Kurikulum 2013, Yogyakarta : Ar Ruzz Media, 2014.

Monks dkk, Psikologi Perkembangan, Pengantar Dalam Berbagai Bagiannya, Yogyakarta : Gadjah Mada University Press, 2001.

Mulyasa, E, Pengembangan dan Implementasi kurikulum 2013, Bandung: Rosdakarya, 2013.

Ningrum, Ary Puspita, dkk, Brain Gym Video Model for Improving the Beginning Writing Abilities of the Autistic Students, Journal of ICSAR, Vol 2, No 2, 2018, url : journal2.um.ac.id/index.php/icsar/article.

Pannen, Paulina dkk, Konstruktifisme dalam Pembelajaran, Jakarta: Proyek Pengembangan Universitas terbuka Direktorat Jenderal Pendidikan Tinggi Departemen Pendidikan Nasional, 2001.

Pribadi, Benny A., Desain Dan PengembanganProgram Pelatihan Berbasis Kompetensi: Implementasi Model ADDIE, Jakarta: Prenada Media Group, Cet. 2, 2016.

Ramdani, Rijki, dkk, Media Pembelajaran E-Learning Dalam Pembelajaran PAI Di SMA Laboratorium Percontohan UPI Bandung, Jurnal Tarbawy, Vol. 5, No. 1, 2018. 
Saefullah, Aep, Penerapan Model Project Based Learning Untuk Mengembangkan Soft Skill Dan Kualitas Hasil Belajar Siswa Pada Pembelajaran PAI Di SMA Avicenna Cinere, Jurnal Pendidikan Kewarganegaraan, Universitas Pamulang, Vol. 5, No. 2, 2018.

Sahrodi, Jamali, Metodologi Studi Islam (Menelusuri Jejak Historis Kajian Islam ala Sarjana Orientalis, Bandung : Pustaka Setia, 2008.

Shihab, M. Quraish, Membumikan Al Qur'an: Fungsi dan Peran Wahyu Dalam Kehidupan Masyarakat, Bandung : Mizan Pustaka, 2007.

Siregar, Evelin, Hartini Nara, Bahan Ajar Teori Belajar dan Pembelajaran, Jakarta : MKDK FIP UNJ, 2007.

Sugiono, Metode Penelitian Kuantitatif, Kualitatif dan R\&D, Bandung: Alfabeta, 2011.

Sumanto, Buletin Psikologi; Kajian Psikologis Kebermaknaan Hidup, UPFPSI UGM, Vo14, 2006.

Suparno, Paul, Teori Perkembangan Kognitif Jean Piaget, Yogyakarta : Kanisius, 2003.

Taufiq, Ainul Uyuni, Pengembangan Tes Kognitif Berbasis Revisi Taksonomi Bloom Pada Materi Sistem Reproduksi Untuk Siswa SMA, Jurnal Biotek, Vol. 3, No. 2, 2015, url : journal.uin-alauddin.ac.id/index.php/biotek/article.

Tjahjadarmawan, Elizabeth, Best Practice Guru Dalam Pembelajaran Di Sekolah, Yogyakarta: Deepublish, Cet 1, 2016.

Wahid, Abd Hamid, Rizka Afkarina Karimah, Integrasi Higher Order Thinking Skill (HOST) Dengan Model Creative Problem Solving, Jurnal Modelling, Jurnal Prodi PGMI STIT NU Al Hikmah, Vol. 5, No. 1, 2018.

Walgito, Bimo, Psokologi Sosial, Yogyakarta: Andi Offset, 1990.

Wawan \& Dewi M, Teori \& Pengukuran Pengetahuan, Sikap dan Perilaku Manusia, Yogyakarta: Mulia Medika, 2011.

Wibowo, AM, Internalisasi Nilai-nilai Karakter Bangsa Melalui Mata Pelajaran PAI Pada SMA Eks RSBI Di Pekalongan, Analisa: Journal of Social Science and Religion, Balitbang Kemenag Semarang, Vol. 21, No. 2, 2014.

Yusuf, S., Psikologi Perkembangan Anak Dan Remaja, Bandung: Rosda, 2004. 